\title{
Społeczne obowiązki własności prywatnej
}

Wynikające z posiadania prawo do użytkowania i dysponowania dobrami nie jest nieograniczone. Kościół od wieków stał na straży własności prywatnej: targnięcie się na tę własność w postaci kradzieży, podpalenia itp. traktowane było w kategoriach grzechu i obłożone $\mathrm{z}$ tej racji surowymi sankcjami kościelnymi. Nie znaczy to jednak, że Kościół stał na stanowisku zupełnej dowolności w dysponowaniu, w szczególności dla celów osobistej konsumpcji, tą własnością. Obżarstwo i pijaństwo uważane były za grzech niezależnie od pozycji społecznej jednostki ${ }^{1}$. Posiadanie dóbr materialnych, jakkolwiek stanowi prawo osoby, jest wielorako uwarunkowane przez strukturę ludzkiej osobowości i przez racje dobra społecznego. Posiadanie dóbr jest więc też funkcją społeczną. Osoba posiadająca rzeczy materialne i dysponująca nimi jest powołana do tego, by przyczyniała się do dobra swoich bliźnich oraz do dobra wspólnego społeczności, w której żyje.

Uzasadnieniem celu społecznego prywatnej własności jest zasada prawa naturalnego mówiąca, że Bóg stworzył dobra materialne dla wszystkich ludzi, nie dla jednostek. Nikt nie powinien uważać za własne tego, co dostał z przydziału. Uznaje się wprawdzie prawowitość zawłaszczenia, lecz tylko w pewnych granicach i z krytyczną oceną sytuacji. Zawłaszczenie jest nadużyciem i występkiem, gdy biedni nie mają w nim udziału. „Nauka dwunastu apostołów”, tekst z II wieku chrześcijaństwa, poucza: „Będziesz dzielił z braćmi wszystkie dobra i nie nazwiesz ich twoją własnością" ${ }^{2}$ Święty Jan Chryzostom, jeden z greckich ojców Kościoła, przypomina: „Co Bóg nam przydzielił, nie jest naszą własnością, lecz

Por. S. Piekarczyk, Barbarzyńcy i chrześcijaństwo, Warszawa 1968, s. 103-104.

2 Patres apostolici, ed. F. X. Funk, Tübingen 1887, s. 16-17. 
raczej wspólną. To jest zgodne z naturą. Dał nam jako wspólną, byśmy się nauczyli oddawać do wspólnego użytku" . Podobną naukę głosili ojcowie łacińscy, w tym św. Ambroży, którego słowa przytacza encyklika Pawła vi Populorum progressio: „Nie z twego własnego dobra dajesz biednemu, ale oddajesz mu to, co do niego należy. Albowiem przywłaszczasz sobie to, co jest dane jako wspólne, na użytek wszystkich. Ziemia dana jest wszystkim, a nie tylko bogatym"4.

Doktryna ojców Kościoła na temat społecznych obciążeń własności prywatnej sprowadza się do stwierdzenia, że ziemia została oddana wszystkim ludziom. Nikt więc nie powinien nazywać własnością tego (proprium nemo docat), co wziął ze wspólnego mienia, ponad to, co wystarcza (quod e communi plusquam sufficeret). Średniowieczna myśl, rozważając te zasady i wnioski, wyraziła je w sposób stanowczy:

1. Wszystkie dobra są wspólną własnością wszystkich ludzi, co wynika z prawa naturalnego. Niektórzy twierdzili nawet, że wspólnota z prawa boskiego należy do stanu pierwotnej natury, a własność do stanu natury po upadku (naturae lapsae). Stąd troska o wspólne dobro, w takim stopniu jak o dobro własne, sprawia ludziom wielką trudność, a powszechne stało się praktykowane zawłaszczenie odnośnie do dóbr konsumpcyjnych lub użytkowych.

2. Przeznaczenie wspólnotowe jest wcześniejsze od zawłaszczenia. Prawo własności jest drugorzędnym prawem ludzkim, którego celem jest ułatwienie dobrego użytkowania dóbr.

3. W razie potrzeby przeznaczenie do wspólnego użytkowania ma pierwszeństwo przed prawem własności. Tak więc np. człowiek znajdujący się w ostatecznej potrzebie, tj. w niebezpieczeństwie utraty życia (in extrema necessitate), ma ścisłe prawo do zabrania sobie takiej ilości dóbr materialnych, która jest konieczna do uchronienia go od śmierci, a właściciel ma obowiązek pozwolenia mu na skorzystanie $\mathrm{z}$ tego prawa. Odmówienie mu tego prawa byłoby przeciwdziałaniem prawu natury. Dlatego w teologii moralnej przyjęto zasadę: „w ostatecznej potrzebie wszystko staje się wspólnym"s.

3 Jan Chryzostom, Homilie na I List do Tymoteusza, 13.

4 Św. Ambroży, O Nabocie (De Nabuthe Jezraelita), 12.

5 R. Laurentin, Rozwój a zbawienie, tłum. Z. Włodkowa, Warszawa 1972, s. 115-117; J. Piwowarczyk, Katolicka etyka społeczna, t. 2, Londyn 1963, s. 53-55. 
Nauka Kościoła o społecznym obciążeniu własności prywatnej została przypomniana w szeregu współczesnych dokumentów nauczania Kościoła. Pius XI w encyklice Quadragesimo anno (1931) uczył, że „przy używaniu własności trzeba mieć na względzie nie tylko własne korzyści, ale i dobro ogółu"6. Jan xxıII w encyklice Mater et magistra (1961) głosił, że własność jest funkcją społeczną: „U samych podstaw prawa własności prywatnej tkwi jego funkcja społeczna. W istocie rzeczy bowiem zasoby wszelkich dóbr mają z woli Boga Stwórcy służyć w pierwszym rzędzie do zapewnienia wszystkim ludziom właściwego poziomu życia"'. Jan Paweł II w encyklice Sollicitudo rei socialis (1987) przypomniał „typową zasadę chrześcijańskiej nauki społecznej: dobra tego świata zostały pierwotnie przeznaczone dla wszystkich. Prawo do własności prywatnej jest słuszne i konieczne, ale tej zasady nie niweczy. Ciąży bowiem na własności «hipoteka społeczna», czyli uznaje się jako jej wewnętrzną właściwość funkcję społeczną, mającą swoją podstawę i uzasadnienie właśnie w zasadzie powszechnego przeznaczenia dóbr"8.

Funkcja indywidualna dóbr polega na rozwijaniu inicjatywy osobistej i na zabezpieczaniu przyszłości człowieka i jego rodziny. Zaś funkcja społeczna wymaga, by wszystkie grupy społeczne miały dostęp do koniecznych środków do życia w sposób godny człowieka i posiadały konkretną możliwość np. zakupu także dóbr nieruchomych: domu, środków produkcji (np. warsztatu) ${ }^{9}$. Społeczny wymiar własności prywatnej wyraża się także jej wpływem na kształtowanie się całości systemów politycznych. Jak słusznie zauważono, nierówny podział własności jest istotną bazą wszelkiej polityki, a w każdym społeczeństwie różnorodność grup ekonomicznych prowadzi do różnorodności programów politycznych i współtworzy tzw. „psychologię polityczną” danej społeczności ${ }^{10}$.

W swej istocie społeczne obowiązki własności prywatnej dotyczą zarówno własności konsumpcyjnej, jak i własności produkcyjnej.

${ }^{6}$ QA 49.

7 MM 119.

${ }^{8}$ SRS 42.

9 Por. J. Mazur, Na ścieżkach Ewangelii pracy, Kraków 1997, s. 98-102; A. Rauscher, Własność prywatna w stużbie człowieka pracujacego, w: Własność i demokracja, wybór i oprac. P. Kaczanowski, Warszawa 1995, s. 102-128.

${ }^{10}$ Por. V. L. Parrington, Główne nurty myśli amerykańskiej 1620-180o, tłum. H. Krzeczkowski, Warszawa 1968, s. 411-412. 
W dziedzinie konsumpcji obowiązki właściciela sprowadzają się do poszukania najlepszego możliwego sposobu konsumpcji oraz przekazania na cele społeczne nadwyżki dochodów ${ }^{11}$.

Do obowiązków moralnych właściciela należy umiejętne i właściwe używanie dóbr, które posiada. Niedopuszczalne jest ich marnotrawienie - sprzeciwia się ono prawu natury, gdyż naturalnym przeznaczeniem dóbr jest zaspokojenie takich potrzeb, które mogą zaspokoić najlepiej. Marnotrawstwo byłoby wyrazem egoizmu, brakiem opanowania samego siebie, wprowadzałoby chaos w świat rzeczy i dóbr materialnych ${ }^{12}$.

Przekazanie przez właściciela na cele społeczne nadwyżek dochodów wiąże się z pojęciem jego słusznych potrzeb. Słuszne potrzeby właściciela obejmują potrzeby jego rodziny, a mogą rozszerzyć się na potrzeby dalszych krewnych, domowników, przyjaciól, podwładnych i pracowników. Słuszne potrzeby obejmują środki konieczne do godziwego życia. Przy ich ustalaniu niezbędne jest uwzględnienie trzech poziomów potrzeb lub konieczności: potrzeb wspólnych wszystkim ludziom, tj. potrzeb życiowych (necessaria vitae), potrzeb wynikających z przynależności do danego stanu (necessaria status) oraz potrzeb reprezentacyjnych związanych z wypełnianiem określonej funkcji społecznej (status docentia). Dobra, które pozostają właścicielowi po zaspokojeniu własnych potrzeb, nazywa się dobrami zbytecznymi (bona superflua). Mogą one być, paralelnie do potrzeb, zbyteczne dla życia, dla stanu i dla pełnionej funkcji społecznej.

Kościół zawsze uczył, iż dobra zbyteczne właściciel winien obracać na rzecz potrzebujących. Święty Bazyli głosił: „Do nagiego należy płaszcz, który masz schowany w skrzyni; do bosego buty, które butwieją u ciebie"13. Święty Augustyn pisał: „dobra zbyteczne bogatych są dobrami koniecznymi ubogich. Cudze rzeczy posiada, kto posiada rzeczy zbyteczne"14. Powoływano się przy tym na słowa Pisma Świętego: „Bogatym na tym świecie nakazuj, by nie byli wyniośli, nie pokładali nadziei w niepewności bogactwa, lecz w Bogu, który nam wszystkiego obficie udziela do używania, niech czynią dobrze, bogacą się w dobre czyny, niech będą hojni,

${ }^{11}$ Por. S. Jarocki, Katolicka nauka społeczna, Paris 1964, s. 496-50o.

${ }_{12}$ H. Camara, Godzina Trzeciego Świata. Wybór pism, tłum. J. Bukowski i in., Warszawa 1973, s. 26-27.

${ }_{13}$ Św. Bazyli Wielki, Homilia na stowa Ewangelii Łukasza (12, 18): „Zburze swe spichrze, a pobuduję większe” i o chciwości (Homilia in illud Lucae „Destruam”), 7.

${ }^{14}$ Św. Augustyn, Homilie na Ewangelie św. Jana (Joan. Evang., tract. vI), 25. 
uspołecznieni, odkładając do skarbca dla siebie samych dobrą podstawę na przyszłość, aby osiągnęli prawdziwe życie” (1 Tm 6, 17-19).

Obowiązek ten wyjaśnia m.in. Pius XI w encyklice Quadragesimo anno, w której czytamy: „Nasuwa się tu sprawa wolnych dochodów, to jest tych, które człowiekowi zostają po opędzeniu potrzeb związanych z utrzymaniem się na stopie przyzwoitości i odpowiednio do zajmowanego stanowiska. Człowiek nie ma zupełnej swobody w rozporządzaniu nimi. Przeciwnie, zarówno Pismo święte, jak i Ojcowie Kościoła bardzo stanowczo uczą, że na bogaczach spoczywa poważny obowiązek praktykowania jałmużny, dobroczynności i wspaniałomyślności”'15. Komentatorzy encykliki podkreślali, że w tekście tym papież formułuje trzy zasady:

1. Obowiązkowi oddania na rzecz ubogich podlegają jedynie „wolne dochody” (reditus liberi), a nie w ogóle „dobra zbyteczne” (bona superflua), czyli zbyteczne dochody, a nie zbyteczne dobra wytwórcze (ziemia, fabryki), bo te, jako źródło dochodu, winny być według możności utrzymane, a nawet rozwijane, co często leży w interesie społecznym.

2. Właściciel zachowuje prawo własności w stosunku do wolnych dochodów, których naruszenie przez drugich pociąga za sobą konieczność restytucji lub odszkodowania.

3. Właściciel nie ma jednak prawa do używania ich na swoje potrzeby, gdyż te zostały w zupełności zaspokojone, a do wykonania pozostaje obowiązek oddania tych dochodów na rzecz potrzebujących.

Pius XI wskazuje również na sposoby wykonania owego obowiązku. Należą do nich: jałmużna (wspieranie poszczególnych potrzebujących), dobroczynność (popieranie dzieł mających na celu opiekę nad potrzebującymi - instytucji charytatywnych, fundacji, państwowej opieki społecznej itp.) oraz wspaniałomyślność (wielkie wydatki, które przynoszą wielkie dobro społeczne, cnota o szczególnym znaczeniu dla kultury, jak popieranie sztuki, szpitali, szkół, a także tworzenie nowych możliwości pracy - wspaniałomyślność nie upokarza biednego, lecz daje mu możność zapracowania sobie na utrzymanie) ${ }^{16}$.

Jan XxIII w encyklice Mater et magistra przypomniał o dużym znaczeniu dobroczynności we współczesnym świecie: „Chociaż w naszych czasach zwiększyły się znacznie i stale ulegają rozszerzeniu zadania państwa

\footnotetext{
15 QA 50.

16 J. Piwowarczyk, Katolicka etyka społeczna, t. 2, s. 56-64.
} 
oraz innych instytucji publicznych, nie można $z$ tego wcale wyciągnąć wniosku, że - jak to się niektórym wydaje - własność prywatna straciła swe społeczne znaczenie. Ta jej społeczna funkcja czerpie bowiem swą moc z samego prawa własności. Łączy się z tym fakt, że zawsze istnieją zarówno niezliczone ciężkie sytuacje, jak i ukryte, a palące potrzeby, których nie jest w stanie uwzględnić i którym w żaden sposób nie można zaradzić, niezmiernie rozbudowana opieka państwa. Dlatego zawsze będzie istnieć szerokie pole do działania dla dobroczynności prywatnej i chrześcijańskiej miłości bliźniego. Jest wreszcie oczywiste, że w poczynaniach, których celem jest dobro duchowe, lepsze wyniki osiągają wysiłki jednostek względnie stowarzyszeń prywatnych aniżeli starania władz państwowych"17.

W dziedzinie produkcji obowiązki właściciela odnoszą się do takiego zarządu majątkiem, który maksymalizuje dochód i prowadzi do zwiększenia kapitału wytwórczego. Wynika to z postulatu rozumu, który nakazuje podejmować wysiłki w celu osiągnięcia najlepszego, a nie gorszego, dochodu, a ponadto kapitał wytwórczy jest, obok pracy, czynnikiem zaspokajania potrzeb społecznych w drodze inwestycji. Prawo natury domaga się odpowiedniej kolejności zaspokajania potrzeb społecznych z dochodu przedsiębiorstwa: najpierw płace, następnie potrzeby właściciela, a na końcu inwestycje. Płaca i potrzeby właściciela żądają zaspokojenia ze względu na prawo natury i naturalny cel pracy. Obowiązek przeznaczenia części dochodu na inwestycje dotyczy zaspokojenia przyszłych potrzeb całego społeczeństwa. Dalsza kolejność zaspokajania tych potrzeb wynika z mniejszej ich bezpośredniości i większego oddalenia w czasie ${ }^{18}$.

Wszyscy ludzie mają prawo do użytkowania dóbr materialnych. Prawo zakazujące pozbawienia człowieka dostępu do nich określa się mianem zabezpieczeń społecznych, które dotyczą podstawowego i powszechnego prawa osoby ludzkiej. II Sobór Watykański uczy: „Bóg przeznaczył ziemię ze wszystkim, co ona zawiera, na użytek wszystkich ludzi i narodów, tak by dobra stworzone dochodziły do wszystkich w słusznej mierze - w duchu sprawiedliwości, której towarzyszy miłość” ${ }^{19}$.

\footnotetext{
17 MM 120.

${ }_{18}$ S. Jarocki, Katolicka nauka społeczna, s. 498-499.

19 KDK 59; por. A. Dylus, Kapitalizm bez właścicieli. Upowszechnienie prywatnego posiadania, w: Własność i demokracja, s. 7-18.
} 
Od dawna władza państwowa była postrzegana jako straż i narzędzie sprawiedliwości społecznej. W klasycznej definicji państwa, którą podał Jean Bodin w 1576 roku w wydanych wówczas Sześciu księgach o Rzeczypospolitej, czytamy, że jest to „suwerenna społeczność, zorganizowana politycznie dla osiągnięcia wspólnych celów i zaspokojenia wspólnych potrzeb” ${ }^{20}$ „Wspólne potrzeby” są więc u źródeł pochodzenia państwa.

John Locke (1632-1704) w następujący sposób wyłożył teorię o ekonomicznych podstawach państwa: „Gdyby człowiek w stanie natury był tak wolny, jak to powiadano, gdyby był absolutnym panem swej osoby i własności, gdyby był równy największym i nie podlegał nikomu, czemuż tedy rozstawałby się ze swą wolnością, tym królestwem, i poddawał się panowaniu i kontroli jakiejś innej potęgi? Odpowiedź na to jest oczywista, chociaż bowiem w stanie natury miał ona prawa tak wielkie, korzystanie $\mathrm{z}$ nich było bardzo niepewne i wciąż wystawione na ataki ze strony innych, ponieważ wszyscy byli królami tak samo jak on, każdy był mu równy i większość niezbyt ściśle przestrzegała słuszności i sprawiedliwości, korzystanie z własności było wówczas bardzo niebezpieczne, bardzo niepewne. Powoduje to, że człowiek pragnie uwolnić się od tego stanu, który jakkolwiek wolny, pełen jest strachu i stałego niebezpieczeństwa. Nie bez powodu więc człowiek szuka wyjścia ze stanu natury i pragnie wejść do społeczeństwa wraz z innymi ludźmi, którzy bądź już są połączeni, bądź mają zamiar się połączyć po to, by wzajemnie chronić swoje życie, wolność i dobra, które określam ogólną nazwą własności. [...] Tak więc wielkim i głównym celem ludzi łączących się w rzeczpospolitą i poddających się rządowi jest zachowanie własności. W stanie natury brakuje im do tego wielu rzeczy"21.

Uspołecznienie relacji międzyludzkich dokonuje się w warunkach uświadomienia sobie wspólnego pożytku, który można wyzwolić przez budowanie struktur jedności. Jest to tajemnica każdego prawdziwego zespolenia i rytm procesu uspołecznienia. Na tym także polega tajemnica miłości: im miłość jest pełniejsza, tym bardziej wyzwala jednostkę $e^{22}$.

${ }^{20}$ Zob. H. Becker, H. E. Barnes, Rozwój myśli społecznej od wiedzy ludowej do socjologii, t. 1, tłum. J. Szacki i in., Warszawa 1964, s. 258.

${ }^{21}$ J. Locke, Second essay of civil government, ed. H. Morley, London 1884, s. 123, 124.

${ }^{22}$ Por. M.-D. Chenu, O teologie pracy, w: Ku powszechnej cywilizacji pracy, Warszawa 1963 , s. $122-127$. 
Na konieczność budowania międzyludzkich relacji wskazuje zasada solidarności (łac. solidare - mocno łączyć ze sobą), która oznacza wzajemną więź i zobowiązanie między osobami. Odrzuca w ten sposób zarówno indywidualizm (zaprzecza społecznej naturze człowieka), jak i kolektywizm (pozbawia człowieka jego osobistej niepowtarzalności, podmiotowości i godności). Zachodnioniemiecki Sąd Najwyższy, w orzeczeniu z 20 lipca 1954 roku, sformułował tę zasadę w następujący sposób: „zgodnie z Konstytucją, człowiek nie jest wyizolowaną suwerenną jednostką. Konflikt między jednostką a społeczeństwem należy rozwiązywać raczej uznając bliski związek jednostki ze społeczeństwem, jego wspólnotowe zakorzenienie, nie naruszając jednocześnie właściwej mu wartości" ${ }^{\prime 2}$.

Próbą połączenia racjonalności, efektywności i rozmachu gospodarki rynkowej, zgodnego z zasadą solidarności, jest społeczna gospodarka rynkowa ${ }^{24}$. Jej rezultatem jest obfitość dóbr i usług, wysoki poziom płac i dochodów, rosnący majątek z rozbudowanym systemem zabezpieczeń społecznych i środków zmniejszających rażące dysproporcje społeczne. O jej powodzeniu świadczy m.in. potoczne określenie sukcesów powojennej gospodarki Niemiec Zachodnich, gdzie realizowano społeczną gospodarkę rynkową, „cudem gospodarczym”. Składają się na niego: wysoki wzrost gospodarczy, pełne zatrudnienie, zrównoważony bilans płatniczy, stabilność cen, korzystna pozycja w handlu zagranicznym oraz „dobrobyt dla wszystkich”. Zakładając solidarność wszystkich obywateli, państwo społeczne prowadzi politykę pomocy tym jednostkom i grupom, które znalazły się w trudnej sytuacji życiowej. Podejmuje się także zabezpieczenia swych obywateli przed ryzykiem, jakie niosą ze sobą starość, choroba, kalectwo, bezrobocie. Do filarów państwa społecznego należą obowiązkowe ubezpieczenia społeczne, które gwarantują wypłatę rent i emerytur, zasiłków chorobowych i zasiłków dla bezrobotnych. Świadczenia zostają uskutecznione dzięki własnym

${ }^{23}$ Orzeczenia Federalnego Sądu Konstytucyjnego 4, 120. Cyt. za: J. Höffner, Gospodarka światowa w świetle katolickiej nauki społecznej, w: Jan Paweł II i in., Kościół i ekonomia, Warszawa 1996, s. 26.

${ }^{24}$ Pojęcie soziale Marktwirtschaft zostało wprowadzone po raz pierwszy w 1946 r. przez Alfreda Müllera-Armacka. Zob. A. Müller-Armack, Wirtschaftslenkung und Marktwirtschaft, w: tenże, Ausgewahlte Werke. Wirtschaftsordnung und Wirtschaftpolitik, Bern-Stuttgart 1981, s. 49. 
składkom ubezpieczonych. Istnieje dzięki temu solidarna równość wewnątrz wspólnoty ubezpieczonych ${ }^{25}$.

Zasada solidarności dotyka zagadnienia tak podstawowego, jak prawa osoby ludzkiej. Dotyczy zwłaszcza prawa osoby do życia w godziwych warunkach oraz szeregu praw ekonomicznych, w tym: prawa do ludzkich, nieszkodliwych, dających samozadowolenie, poczucie wolności, umożliwiających nabycie własności prywatnej warunków pracy; prawa do korzystania z dóbr kulturalnych, a więc do otrzymania właściwego wykształcenia, które jest najbardziej elementarną wartością moralną i kulturalną; prawa do sprawiedliwej płacy; do prywatnej własności dóbr i środków ich wytwarzania; prawa do zwoływania zebrań i zgromadzeń; prawa do słusznej i skutecznej obrony swych praw; prawa do oddawania czci Bogu zgodnie $\mathrm{z}$ własnym przekonaniem i sumieniem itp. ${ }^{26}$

Indywidualna i społeczna funkcja własności może być harmonijnie rozwijana jedynie w społeczeństwie upodmiotowionym, gdyż tylko wówczas służy ona właściwie pojętemu dobru wspólnemu. Klasyczną definicję dobra wspólnego podał Jan xxıII, który napisał w encyklice Mater et magistra, że „dobro wspólne obejmuje całokształt takich warunków życia społecznego, w jakich ludzie mogą pełniej i szybciej osiągnąć swą własną doskonałość" ${ }^{27}$.

Zasada dobra wspólnego określa uprawnienia „od góry” i obowiązki „od dołu”, a więc społeczność mniejsza (jednostka) ma dokonywać wkładu w dobro wspólne społeczności większej (rodziny, środowiska, państwa, świata): społeczność mniejsza społeczności większej, a wszystkie jednostki ludzkie i społeczności - w dobro wspólne rodziny ludzkiej ${ }^{28}$.

Czynnikiem konkretyzacji idei dobra wspólnego jest nastawienie się ludzi na współdziałanie. Dobro wspólne jest bowiem rzeczywistością bardzo złożoną, stąd wypracowywać je muszą zarówno poszczególni ludzie, jak i całe wspólnoty, zespoły, a nawet całe społeczności. Na dobro wspólne, w sensie warunków rozwoju, muszą się składać dostępne dla

${ }^{25}$ A. Dylus, Moralność krańcowa jako problem dla katolickiej nauki społecznej, Warszawa 1992, s. 117-120.

${ }^{26}$ Por. H. Camara, Godzina Trzeciego Świata. Wybór pism, s. 27-30; M. Nieduszyński, Wolność gospodarcza, „Zarządzanie i Edukacja” 7 (1998), nr 1, s. 130-132.

${ }^{27}$ MM 65.

${ }^{28}$ W. Piwowarski, Własność w społecznym nauczaniu Kościoła, „Klub Inteligencji Katolickiej. Zeszyty Społeczne" (1996), nr 4, s. 5. 
wszystkich dobra duchowe i materialne, czystość środowiska naturalnego, możliwości rozwijania swej osobowości przez każdego człowieka. A to wszystko wymaga odpowiednich struktur i infrastruktury, instytucji, kierownictwa i innych czynników życia, działania i rozwoju społecznego. Żadne uproszczenie i jednostronność nie ułatwią rozwoju dobra wspólnego w wysoko rozwiniętej społeczności ${ }^{29}$. Zakłada ono istnienie świata pluralistycznego. W systemach totalitarnych budowanie wspólnego dobra napotyka na ogromne przeszkody, a wręcz jest niemożliwe.

Rozwój dobra wspólnego jest ściśle związany z integralnym rozwojem osoby, czyli z dobrem osoby ludzkiej. Warunkiem kształtowania dobra wspólnego jest podmiotowość społeczeństwa, która - jak przypomniał Jan Paweł II w Laborem exercens - tylko wówczas jest zabezpieczona, gdy zostają powołane do życia organizmy pośrednie (między jednostką a państwem) o celach gospodarczych, społecznych, kulturalnych, które cieszą się rzeczywistą autonomią w stosunku do władz publicznych ${ }^{30}$. Powstające $\mathrm{w}$ procesie uspołecznienia stowarzyszenia umożliwiają realizację wielu praw osoby ludzkiej, zwłaszcza w życiu gospodarczym i społecznym. „Dotyczy to w szczególności zabezpieczenia środków utrzymania, opieki zdrowotnej, upowszechnienia i podniesienia poziomu wykształcenia podstawowego, odpowiedniego przygotowania zawodowego, poprawy sytuacji mieszkaniowej, warunków pracy i należytego odpoczynku"31.

W procesie upodmiotowienia społeczeństwa podstawowym zagadnieniem pozostaje fakt posiadania własności. Można powiedzieć, że zakres prywatnej własności zakreśla obszar upodmiotowienia społeczeństwa. To dlatego w totalitaryzmie własność prywatna zostaje znacznie ograniczona.

Brak upodmiotowienia społeczeństwa, związany z brakiem własności, stał się przyczyną upadku Rzeczypospolitej. Hugo Kołłątaj napisał: „milionowy niewolnik na rozbiór Rzeczypospolitej spoglądał z obojętnością, tak właśnie, jak wprawiony do jarzma wół rozwozi ćwierci nieszczęśliwych a podobnych do siebie ofiar; jak ptak, siedzący na drzewie, spokojnie

${ }^{29}$ F. Woronowski, O właściwa postawę robotników, Lubaczów-Łomża 1987, s. 147. Por. W. Heller, Hannah Arendt: źródła pluralizmu politycznego, Poznań 200o, s. 88-104.

${ }^{30}$ Por. LE 14.

${ }^{31}$ Mм 61; por. J. Szymczyk, Dobro osoby a dobro wspólne, „Dzień Katolicyzmu Społecznego Kıк” (Lublin) (1997), nr 5, s. 18-20; P. Jarecki, Podmiotowość społeczeństwa w stużbie dobru wspólnemu, „Życie i Myśl” 424 (1994), nr 4, s. 14-20. 
patrzy, gdy chciwy połowu myśliwiec ugania się w kniei za niedźwiedziem i wilkiem"32. Karol Libelt w rozprawie $O$ odwadze cywilnej pisał: „Od kogo wymagamy miłości ojczyzny, ten powinien być obywatelem”33.

O antycywilizacyjnym „duchu wyłączności” pisał Stanisław Staszic (1755-1826) w swym najambitniejszym dziele pt. Ród ludzki. Jak zauważył: „wszelki duch wyłączności jest najszkodliwszym i najuporczywszym przeciwnikiem cywilizacji. On od samego wszczynania się towarzystw aż do ich ostatniego udoskonalenia jest i będzie największą dla ogólnego dobra zaporą. On w zaburzeniach, w wojnach, w nieporządku rośnie, tuczy się z krzywdą ogółu, a w zgodzie, w pokoju, w porządku wkrótce odkryty, poznany nikczemnieje i ginie. On jest jednym twórcą tych wieków średnich, wieków barbarzyństwa. Jak w tym duch wyłączności ziemi, urodzenia, honoru, bojarstwa, wiar zabobonnych, tak w dalszym postępie cywilizacji, gdy te duchy już słabnąć i upadać zaczną, on wzniesie się i powstanie w wyłączności handlu i ten będzie zaburzał najdłużej Europę, będzie ją miotał z wojen w wojny jedynie końcem rozrywania związków narodów, końcem niszczenia ich się porozumień. On najmocniej stanie przeciwko rozwinięciu się ostatniej zasady cywilizacji, przeciwko stałemu pokojowi, przeciwko zrzeszeniu się narodów Europy"34.

Konstrukcja „wspólnego dobra” nie jest czymś sztucznym, lecz bardzo konkretnym dziełem osadzonym w trwałej wspólnocie duchowej jednostek i społeczności. Nieprecyzyjność pojęcia dobra wspólnego stwarza trudności w jego szczegółowym wyartykułowaniu, lecz z pewnością łączy się z tym wszystkim, co buduje jedność międzyludzką: pewien stopień równości, sprawiedliwość zmierzającą do harmonii, otwartość warunków, w jakich dochodzi do nawiązywania wzajemnych stosunków i wymiany. Wspólne dobro jednostek, małych grup i społeczności, gwarantowane przez prawo i decyzje polityczne, rozszerza się, by stać się dobrem wspólnym całego społeczeństwa ${ }^{35}$.

Każde działanie i praca są jednocześnie współdziałaniem w budowaniu dobra wspólnego. Jan Paweł II w encyklice Centesimus annus (1991) podkreśla: „Poprzez swoją pracę człowiek angażuje się nie tylko dla

${ }^{32}$ H. Kołłątaj, Prawo polityczne narodu polskiego, Warszawa 179o, s. 38.

${ }_{33}$ Cyt. za: D. Albert, Sprawa ludowa wobec przyszłości narodu, Kraków 1905, s. 9-13.

${ }^{34}$ S. Staszic, Ród ludzki, t. 3, oprac. Z. Daszkowski, Warszawa 1959, s. 178.

${ }^{35}$ Ch. Millon-Delson, Zasada pomocniczości, tłum. C. Porębski, Kraków 1995, s. 89-93. 
samego siebie, ale także dla drugich i z drugimi: każdy współdziałając uczestniczy w pracy i dobru drugiego. Człowiek pracuje dla zaspokojenia potrzeb swojej rodziny i wspólnoty, do której należy, Narodu i w końcu całej ludzkości" ${ }^{\prime 36}$.

Do obowiązków ciążących na własności, poza obowiązkami społecznymi, należą również osobowe obowiązki moralne, które wiążą się z zagadnieniem grzechów i cnót. Mają one przede wszystkim, przy własności jako istotnym ich przedmiocie, wyraźny aspekt społeczny. Grzech, który jest niespełnieniem obowiązków moralnych właściciela, może przybierać postać: skąpstwa, chciwości, egoizmu, zazdrości, rozrzutności, marnotrawstwa. Do cnót, które właściciel może rozwinąć, trzeba zaliczyć: sprawiedliwość, miłość, oszczędność, pracowitość, przezorność, gospodarność, hojność i wielkoduszność. Bardzo dużą rolę we władaniu dobrami gospodarczymi odgrywają miłość i sprawiedliwość. Pomiędzy nimi zachodzi ścisły związek, który można wyrazić za pomocą dwóch reguł:

1. Wszystko, co właściciel ma przekazać ze swego dochodu na cele społeczne z nakazu miłości, objęte jest również wymogiem sprawiedliwości.

2. To, co właściciele dają z tytułu sprawiedliwości, powinno być rozdzielane pomiędzy potrzebujących zgodnie z cnotą miłości i roztropności. Sprawiedliwość wskazuje, ile oddać na cele społeczne, a miłość - ile komu dać z ogólnej kwoty wolnych dochodów ${ }^{37}$.

Istotnym źródłem destrukcji świata duchowego przez grzechy dotyczące własności jest społeczny wymiar ludzkiej egzystencji. Słusznie zauważył Wiktor Heltman (1796-1874), działacz Towarzystwa Demokratycznego Polskiego, że "gdyby człowiek był istotą czysto indywidualną, gdyby społeczność nie była jego przeznaczeniem, potrzebą, niezbędną koniecznością, gdyby silne, niepokonane, mimowolne uczucie braterstwa nie łączyło nas z innymi ludźmi, ze społecznością, człowiek nie mógłby znaleźć w sobie samym żadnych nabywania własności prawideł, a własnym tylko interesem powodowany, o szczęście drugich i los społeczności całej nie dbający, uważałby własność swoją jakiemkolwiek sposobem nabytą za świętą i nietykalną; gwałt przeto, podstęp, rozbój, rabunek, ujarzmienie byłoby dla niego równie godziwymi środkami nabywania

\footnotetext{
${ }^{36}$ CA 43.

37 S. Jarocki, Katolicka nauka społeczna, s. 498-50o.
} 
własności, obracania na swą korzyść i rzeczy, i ludzi, jak własna jego niepodległa praca"38.

Społeczny wymiar ludzkiej natury zmusza do refleksji nad budowaniem przez człowieka, także za pomocą posiadanej własności, najlepszej możliwej wspólnoty. W tej trosce wyraża się także najgłębsza teologiczna prawda o człowieku, który jest „obrazem Boga” ${ }^{39}$. Staje się nim dzięki swej zdolności do osobowego dialogu z Bogiem, ale także do interpersonalnej wspólnoty wewnątrz rodziny ludzkiej i do panowania nad światem. Wskutek swej cielesności człowiek jest istotowo powiązany ze światem nie może siebie udoskonalić bez jednoczesnego udoskonalania, przekształcania świata. Lecz posiadając wewnętrzną duchowość, jednocześnie przekracza granice świata, żyje w osobowej solidarności z innymi ludźmi.

\section{Bibliografia}

Albert dr, Sprawa ludowa wobec przyszłości narodu, nakł. Drukarni Władysława Teodorczuka, Kraków 1905.

Alfaro J., Teologia postępu ludzkiego, Ośrodek Dokumentacji i Studiów Społecznych, Warszawa 1971.

Ambroży św., O Nabocie (De Nabuthe Jezraelita), wstęp i tłum. R. Pankiewicz, w: św. Ambroży, Wybór pism, cz. 2, tłum. J. Jundziłł i in., Akademia Teologii Katolickiej, Warszawa 1986, s. 5-35.

Augustyn św., Homilie na Ewangelie św. Jana (Joan. Evang., tract. vI), tłum. W. Szołdrski, w: św. Augustyn, Homilie na Ewangelię i Pierwszy List św. Jana, cz. 1-2, tłum. W. Szołdrski, W. Kania, wstęp i oprac. E. Stanula, Akademia Teologii Katolickiej, Warszawa 1977, s. 21-37.

Bazyli Wielki św., Homilia na słowa Ewangelii Łukasza (12, 18): „Zburzę swe spichrze, a pobuduję większe” i o chciwości (Homilia in illud Lucae „Destruam”), tłum. T. Sinko, w: św. Bazyli Wielki, Wybór homilij i kazań, tłum. i wstęp T. Sinko, nakł. Wydawnictwa Mariackiego, Kraków 1947, s. 50-70.

Becker H., Barnes H. E., Rozwój myśli społecznej od wiedzy ludowej do socjologii, t. 1, tłum. J. Szacki i in., Książka i Wiedza, Warszawa 1964.

${ }^{38}$ W. Heltman, Uwagi Centralizacji przy dyskusji nad Manifestem Towarzystwa Demokratycznego Polskiego, w: Towarzystwo Demokratyczne Polskie. Dokumenty i pisma, oprac. R. Baczko, Warszawa 1954, s. 331.

39 J. Alfaro, Teologia postępu ludzkiego, Warszawa 1971, s. 53-68. 
Camara H., Godzina Trzeciego Świata. Wybór pism, tłum. J. Bukowski i in., Biblioteka „Więzi” - Społeczny Instytut Wydawniczy, Kraków-Warszawa 1973.

Chenu M.-D., O teologie pracy, w: Ku powszechnej cywilizacji pracy, Wydawnictwo Pax, Warszawa 1963, s. 122-127.

Dylus A., Kapitalizm bez właścicieli. Upowszechnienie prywatnego posiadania, w: Własność i demokracja, wybór i oprac. P. Kaczanowski, Fundacja ATK, Warszawa 1995, s. 7-18.

Dylus A., Moralność krańcowa jako problem dla katolickiej nauki społecznej, Pallottinum, Warszawa 1992.

Heller W., Hannah Arendt: źródła pluralizmu politycznego, Uniwersytet im. Adama Mickiewicza w Poznaniu, Poznań 2000.

Heltman W., Uwagi Centralizacji przy dyskusji nad Manifestem Towarzystwa Demokratycznego Polskiego, w: Towarzystwo Demokratyczne Polskie. Dokumenty i pisma, oprac. R. Baczko, Książka i Wiedza, Warszawa 1954.

Höffner J., Gospodarka światowa w świetle katolickiej nauki społecznej, w: Jan Paweł II i in., Kościół i ekonomia, Wydawnictwo Societas, Warszawa 1996, s. 23-33.

Jan Chryzostom św., Homilie na I List do Tymoteusza, tłum. T. Sinko, w: św. Jan Złotousty, Homilie na Listy Pasterskie św. Pawła i na List do Filemona, tłum. i wstęp T. Sinko, nakł. Wydawnictwa Mariackiego, Kraków 1949, s. 25-192.

Jan Paweł II, Encyklika Centesimus annus, przedruk: Libreria Editrice Vaticana, Włocławek 1991.

Jan Paweł II, Encyklika Laborem exercens, Wydawnictwo Ośrodka Dokumentacji i Studiów Społecznych, Warszawa 1982.

Jan Paweł II, Encyklika Sollicitudo rei socialis, Ośrodek Chrześcijańskiej Myśli Społecznej Augustinum, Warszawa 1988.

Jan XxıII, Encyklika Mater et magistra, Société d'Éditions Internationales, Paris 1963.

Jarecki P., Podmiotowość społeczeństwa w służbie dobru wspólnemu, „Życie i Myśl” 424 (1994), nr 4, s. 14-20.

Jarocki S. [Strzeszewski Cz.], Katolicka nauka społeczna, Société d’Éditions Internationales, Paris 1964.

Kołłątaj H., Prawo polityczne narodu polskiego, nakł. i druk. Michala Grölla, Warszawa 1790.

Laurentin R., Rozwój a zbawienie, tłum. Z. Włodkowa, Wydawnictwo Pax, Warszawa 1972.

Locke J., Second essay of civil government, ed. H. Morley, London 1884. 
Mazur J., Na ścieżkach Ewangelii pracy, Wydawnictwo Czuwajmy, Kraków 1997. Millon-Delson Ch., Zasada pomocniczości, tłum. C. Porębski, Wydawnictwo Znak, Kraków 1995.

Müller-Armack A., Wirtschaftslenkung und Marktwirtschaft, w: A. Müller-Armack, Ausgewählte Werke. Wirtschaftsordnung und Wirtschaftpolitik, P. Haupt, Bern-Stuttgart 1981, 32-51.

Nieduszyński M., Wolność gospodarcza, „Zarządzanie i Edukacja” 7 (1998), nr 1, s. $130-132$.

Parrington V. L., Główne nurty myśli amerykańskiej 1620-180o, tłum. H. Krzeczkowski, PIW, Warszawa 1968.

Patres apostolici, ed. F. X. Funk, Laupp, Tübingen 1887.

Paweł vi, Encyklika Populorum progressio, Éditions du Dialogue, Paris 1968.

Piekarczyk S., Barbarzyńcy i chrześcijaństwo, pwn, Warszawa 1968.

Pius XI, Encyklika Quadragesimo anno, Te Deum, Warszawa 2002.

Piwowarczyk J., Katolicka etyka społeczna, t. 2, Veritas, Londyn 1963.

Piwowarski W., Własność w społecznym nauczaniu Kościoła, „Klub Inteligencji Katolickiej. Zeszyty Społeczne” (1996), nr 4, s. 5.

Rauscher A., Własność prywatna w służbie człowieka pracującego, w: Własność i demokracja, wybór i oprac. P. Kaczanowski, Fundacja Aтк, Warszawa 1995, s. $102-128$.

Sobór Watykański II, Konstytucja Gaudium et spes, w: Sobór Watykański II. Konstytucje. Dekrety. Deklaracje, Pallottinum, Poznań 2002, s. 526-606.

Staszic S., Ród ludzki, oprac. Z. Daszkowski, t. 3, PwN, Warszawa 1959.

Szymczyk J., Dobro osoby a dobro wspólne, „Dzień Katolicyzmu Społecznego KIK" (Lublin) (1997), nr 5.

Woronowski F., O właściwą postawę robotników, Michalineum, Lubaczów-Łomża 1987 .

\section{Abstrakt}

Wynikające z posiadania prawo do użytkowania i dysponowania dobrami nie jest nieograniczone. Kościół od wieków stał na straży własności prywatnej: targnięcie się na tę własność w postaci kradzieży, podpalenia itp. traktowane było w kategoriach grzechu i obłożone z tej racji surowymi sankcjami kościelnymi. Nie znaczy to jednak, że Kościół stał na stanowisku zupełnej dowolności w dysponowaniu własnością, w szczególności dla celów osobistej konsumpcji. Obżarstwo i pijaństwo uważane były za grzech niezależnie od pozycji społecznej 
jednostki ${ }^{40}$. Posiadanie dóbr materialnych, jakkolwiek stanowi prawo osoby, jest wielorako uwarunkowane przez strukturę ludzkiej osobowości i przez racje dobra społecznego. Posiadanie dóbr jest więc też funkcją społeczną. Osoba posiadająca rzeczy materialne i dysponująca nimi jest powołana do tego, by przyczyniała się do dobra swoich bliźnich oraz do dobra wspólnego społeczności, w której żyje. Społeczny wymiar ludzkiej natury zmusza do refleksji nad budowaniem przez człowieka, także za pomocą posiadanej własności, najlepszej możliwej wspólnoty.

\title{
The social responsibilities of ownership
}

\begin{abstract}
Abstact
The right to use and dispose of goods, resulting from ownership, is not unlimited. The Church stood guard over private property for centuries: encroachment on the property in the form of theft, arson, etc. was considered a sin and for this reason met with stringent sanctions issued by the Church. This does not mean, however, that the Church stood for complete freedom in using the property, in particular for the purpose of personal consumption. Gluttony and drunkenness were considered sins, regardless of the social position of the individual. Although possession of material goods is an individual right, it is in numerous ways conditioned by the structure of the human personality and by the cause of social good. Possession of goods is thus also a social function. A person in possession of and disposing of material things is called on to contribute to the good of his or her neighbors and to the common good of the community in which he or she lives. The social dimension of human nature forces us to reflect on how man can build the best possible community, including with his possessions.
\end{abstract}

${ }^{40}$ Por. S. Piekarczyk, Barbarzyńcy i chrześcijaństwo, Warszawa 1968, s. 103-104. 